\title{
Examining the Effects of Movement Activities of Coordinated Approach to Child Health (CATCH) Program on Locomotor and Manipulative Skills of 4-5 Years Old Children
}

\author{
Zeynep KILIÇ* \\ Faculty of Education, Istanbul Medipol University, Istanbul, Turkey \\ ORCID: 0000-0001-6481-4765 \\ Gülden UYANIK \\ Ataturk Education Faculty, Marmara University, Istanbul, Turkey \\ ORCID: 0000-0001-9947-8159 \\ Saime ÇAĞLAK \\ Ataturk Education Faculty, Marmara University, Istanbul, Turkey
}

ORCID:0000-0002-9393-9492

\section{Article history}

Received:

10.06.2021

Received in revised form: 09.03.2021

Accepted:

12.03.2021

Key words:

Catch movement program,

Locomotor skills,

Manipulative skills
The main objective of the research is to examine the impact of regular implementation of Education Program made of CATCH Program Movement Activities on the locomotor and manipulative skills of preschool children. Implementation of Education Program made of CATCH Program Movement Activities was carried out in an independent preschool located in Kadıköy District in Anatolian Side of İstanbul Province, Turkey. Purposeful sampling method was used to determine the school where the experimental designed study will be conducted. The study group of the research consists of 64 children, 32 in experiment group and 32 in control group. To determine the efficiency of Education Program made of CATCH Program Movement Activities, education program was implemented with experiment groups for two days a week during 9 weeks. According to the results of pre-test and post-test measurements of experiment and control groups, no significant difference was determined between the locomotor subdimension, manipulative subdimension of the measurement instrument and measurement instrument total scores in pre-test measurements of the children ( $p>.05$ ). According to the analysis results of post-test measurements following movement program, it was determined that there is a significant difference in locomotor subdimension, manipulative subdimension of the measurement instrument and measurement instrument total scores of both 4 and 5 years old children in favour of the experiment group $(\mathrm{p}<.05)$.

\footnotetext{
* Correspondency: zeynep.kilic02@gmail.com
} 


\section{Introduction}

Motor development process is a process that starts in the mother's womb and ends only with the end of life. With the physical development of the baby in the mother's womb, the organism's central nervous system, the movement system in the passive dimension of the skeletal system, and the muscular system in the active dimension of the skeletal system begin to develop. Movement occurs as a result of the development and functioning of all these systems in an organized manner. Even though the movement is seen as reflexes in the first years of life and some of them last for a lifetime, some of them become voluntary over time and turn into motor skills.

Even though motor development which is described as the process of voluntary movement of the organism is parallel to the development of the central nervous system and physical growth; that is, the process of controlling the behaviours that occur in motor skills, undergoes changes, it periodically follows a regular sequence (Nalbant, 2015). When these periods are examined, it is seen that the first period is the period of reflexive movements which covers the age range of $0-1$, dominated by reflexes that occur involuntarily and are controlled by the lower brain and form the basis of the stages of motor development. Immediately after the reflexive movements, the first forms of voluntary movements emerge with the development of the musculoskeletal and central nervous systems and the movement possibilities offered to the baby. This phase, which covers the age range of $0-2$, is the period of rudimentary movements. Following the emergence of the rudimentary forms of movements, the phase of fundamental movements, which includes motor control and motor learning, takes place in the child's life very actively and the child acquires fundamental movement skills. Following the emergence of the rudimentary forms of movements comes the phase of fundamental movements, which covers the age range of 2-7, in which motor control and motor learning are intensively involved in the life of the child and in which the child acquires fundamental movement skills. The phase of fundamental movements coincides with the pre-school education years of the child and prepares the ground for the next period, the specialized movement phase (Gallahue, Ozmun \& Goodway, 2012/2014; Muratl1, 2013; Nalbant, 2015).

There are some movements skills that children are expected to acquire and master through practice during the fundamental movements phase. These skills include locomotor skills involving running, gallop, sliding step, leaping, jumping, standing long jump and manipulative skills including throwing, catching, rolling, kicking the ball, hitting a stationary ball with a stick and bouncing the ball (Gallahue et al., 2012/2014; Sevimay-Özer \& Özer, 2014). Reaching the maturity stage in these movement skills is the ultimate goal of the fundamental movement phase. Children who reach the maturity stage in movement skills acquire the relevant skills that they will use throughout their lives. From this point on, they start to combine the movement skills they have mastered and use them in more complex ways, and they include movement in their lives as an element of entertainment, both in sports, dance and in a different field.

In order to reach the maturation stage in movement skills, which is the ultimate goal of the fundamental movement phase, children should be supported both in terms of motivation and with regular movement activities appropriate to their developmental level. While preschool children acquire new movement skills, they may experience fears of being ridiculed or harmed (Nalbant, 2015; Sevimay-Özer \& Özer, 2014). Children who are not motivated to overcome their fears and are not encouraged to try movement skills do not want to participate in movement activities, and children who do not participate in movement activities do not develop their movement skills at the desired level (Sevimay-Özer \& Özer). Teachers and 
families should assume great responsibilities in breaking this vicious circle. Studies have shown that the motivational support and environmental opportunities provided by families and teachers for children increase the physical activity level of children (Cools, Martelaer, Samaey, \& Andries, 2011; Derscheid, Umoren, Kim, Henry, \& Zittel, 2010; Zecevic, Tremblay, Lovsin, \& Michel, 2010). Since this active participation enables the child to move, it helps children to experience movement skills and reach the maturity level in movement skills. It is also known that movement training programs, which are applied regularly and prepared in accordance with the motor development level of the child, positively affect the motor development and movement skills of the child (Günebakan, Saygin, Gelen \& Karacabey, 2009; Scheffer, Ketelhut \& Mohasseb, 2007; Ulutaş, Demir \& Yayan, 2017; Wang, 2004; Yarımkaya \& Ulucan 2015).

In light of the findings reported in the existing literature, the main drive for conducting the current study is to understand whether a movement program implemented in the fundamental movements phase affect all the movement skills of the child without focusing on a specific group of movements; thus, the goal of the current study was set to be to investigate the effect of a movement training program constructed on the basis of the CATCH program movement activities on the locomotor and manipulative skills of children aged 4-5 years old.

To this end, answers to the following research questions were sought:

(1) Do the movement development pre-test mean scores of the experimental and control group children aged 4 vary significantly?

(2) Do the movement development pre-test mean scores of the experimental and control group children aged 5 vary significantly?

(3) Do the movement development pre-test and post-test scores of the experimental group children aged 4 vary significantly?

(4) Do the movement development pre-test and post-test scores of the experimental group children aged 5 vary significantly?

(5) Do the movement development post-test mean scores of the control and experimental group children aged 4 vary significantly?

(6) Do the movement development post-test mean scores of the control and experimental group children aged 5 vary significantly?

\section{Methods}

\section{Research Model}

In order to examine the effectiveness of the Training Program created from the CATCH Movement Activities, the trial model, one of the quantitative research methods, and the "pre-test and post-test model", one of the trial models, was used in the current study.

Quantitative research is a type of research that presents facts and events objectively in an observable, measurable and numerically expressible way. Objectively measuring social behaviours of individuals through observation, experiment and testing and researching them with numerical data are the purpose of this type of research. Trial models refer to a type of research in which the data to be observed are produced under the control of the researcher in order to determine the cause-effect relationships (Karasar, 2015, p.87).

In the pre-test-post-test control group model, there is an experimental group and a control 
group formed through unbiased assignment (Karasar, 2015, p.97). A pre-test is applied to the experimental group and the control group, and after an intervention has been conducted on the experimental group, which is thought to have an effect on the experimental group, the experimental and control groups are subjected to a post-test (Baştürk, 2009, p.36-37).

\section{Study Group}

The implementation of the Training Program created from the CATCH Movement Activities was carried out in an independent kindergarten which is located in Kadıköy district, in the Anatolian side of Istanbul and which has a large multi-purpose hall besides the game hall and allowed the implementation of the movement program in its institutions for a period of school term. As this school could meet the criteria determined for the current study, it was found to be suitable for the purposive sampling method. In this regard, the participants of the study were selected from among the 4 and 5 year-olds receiving their pre-school education in this school. An experimental group and a control group were formed for 4 year-olds and 5year olds, each.

While constructing the experimental and control groups, the classroom teachers were contacted and the children in the classes of the teachers who accepted the implementation of the movement program in their classes were considered to be taken into the experimental groups while the children in the classes of the teachers who did not accept the implementation of the program in their classes were considered to be taken into the control groups. The children who would be included in the experimental and control groups were selected from the classes of the teachers by means of the simple random sampling method. In the experimental and control groups of both age groups (i.e., 4 and 5 year-olds) equal numbers of female and male children were included and thus the study was conducted on a total of 64 children ( 8 female and 8 male children in each group). The distribution of the children in the study group across the groups and genders is given in the table below.

Table 1. The Number of Children in the Experimental and Control Groups According to Age and Gender

\begin{tabular}{lllll}
\hline & & Experimental Group & Control Group & Total \\
\hline \multirow{2}{*}{ 4 Year Olds } & Female & 8 & 8 & 16 \\
& Male & 8 & 8 & 16 \\
\hline \multirow{2}{*}{ 5 Year Olds } & Female & 8 & 8 & 16 \\
& Male & 8 & 8 & 16 \\
\hline Total & & 32 & 32 & 64 \\
\hline
\end{tabular}

\section{Data Collection Tools}

\section{CHAMPS Motor Skills Protocol-(CMSP)}

The CHAMPS Motor Skills Protocol (CMSP) is the product of the study conducted by Harriet G. Williams, Karin A. Pfeiffer, Marsha Dowda, Chevy Jeter, Shaverra Jones and Russel R. in South Caroline in 2009 to introduce a motor skills measurement tool to the literature (Williams et al., 2009).

In the validity study of the CHAMPS Motor Skills Protocol, the TGMD-2 measurement tool was used, and the measurements were conducted by using both of the measurement tools and 
the comparison of the measurement tools was made (Williams et al., 2009). In the comparison of the tests, Pearson correlation analysis was used. According to the results of the analysis, the validity score of the locomotor sub-scales of the CMSP and TGMD-2 scales is .98, it is .97 for the manipulative sub-scales and it is .98 in total (Williams et al., 2009).

In the reliability study of the CHAMPS Motor Skills Protocol, two observers worked with 50 children from 22 schools and the scorings of the two observers were compared. In this regard, the inter-observer consistency score was found to be .99 for the locomotor sub-scale, .98 for the manipulative sub-scale and .94 in total (Williams et., 2009).

The CHAMPS Motor Skills Protocol was adapted to Turkish by Kılıç (2018). Within the scope of validity studies, the Test of Measuring Great Muscle Skills, which measures the same sub-headings and skills as the CHAMPS Motor Skills Protocol, was used for the criterion validity. The correlation values obtained as a result of the analysis made on the subdimensions and total scores of the measuring tools were determined as .89 for locomotor skills, .90 for manipulative skills, and .92 for the total score of the measurement tool $(\mathrm{p}<.01)$.

According to the results of test-retest conducted within the scope of reliability studies, there is a high level of positive correlation $(\mathrm{p}<.01)$ between the first and second measurements in terms of locomotor (.925), manipulative skills (.942) and total motor skills (.941) (p<.01).

The analysis for the internal consistency of the measurement tool was made for each skill in the two sub-dimensions and over the total score of the measurement tool. The values obtained from the locomotor sub-dimension of movement skills were found to be varying between .745 and .915 while the values obtained from the manipulative sub-dimension were found to be between .727 and .968 . The total score of the measurement tool has the internal consistency value of .770 .

As a result of the analyses conducted to determine the consistency between the evaluators, the correlation values between the evaluators were found to be .825 for the locomotor dimension, .915 for the manipulative dimension and .901 for the motor skills total (K1liç, 2018).

\section{Catch Early Childhood Program - It's Fun to be Healthy}

The CATCH (Coordinated Approach to Child Health) program, on which the movement training program used in the current study is based, was formed to fight the obesity seen in children in America, can address the needs of children from different age groups, has a special training kit directed to children in their early childhood, aims to raise awareness in children about a healthy diet, to increase physical activity among children, to develop health policies at schools and to eliminate risk factors among children at risk through early interventions (It's Fun To Be Healthy, 2011; Sharma, Chuang \& Hedberg, 2011).

Only the movements activities of the $\mathrm{CATCH}$, which is a multidimensional health program with proven effectiveness in different points such as ensuring that children make the right choices about healthy eating, increasing the physical activity of children in and out of the classroom, providing support to families through participation studies (Sharma et al., 2011), were considered for the current study. From among these movement activities, movement skills that could be measured and evaluated with the measurement tool used in the current study selected and included in the movement training. 


\section{Data Collection Process}

After the determination of the movement activities that could be measured from among the movement activities involved in the CATCH - (Early Childhood - It's Fun To Be Healthy), the activities found to be suitable for inclusion in the current study were translated from English to Turkish and thus the Training Program created from the CATCH Movement Activities was created (Annex 1).

In order for the translated activities to be implemented, a 9-week application schedule covering the months of February-March and April in the 2016-2017 school year was prepared. Interviews were made with independent kindergartens that could provide the physical environment suitable for the research and sufficient number of children for the experimental-control groups according to the prepared work schedule and the research permission was obtained from the Provincial Directorate of National Education. A meeting was held with the teachers of 4 and 5-year olds who were working in an independent kindergarten, which provided all the physical conditions and allowed the implementation of the Training Program created from the CATCH Movement Activities in their school for a term. The content of the movement program was explained and the teachers who allowed 1 class hour of practice, two days a week during the term were determined. The classes of the teachers who viewed the implementation of the program positively were determined as the experimental group and the other classes as the control group. In this context, pre-tests were administered to determine whether there was any difference between the levels of the experimental and control groups in the middle of February. The results of the pre-test revealed that the groups were equal. With the 4 and 5 age groups determined as the experimental group, the applications were started 2 days a week (Tuesday and Thursday) and 1 class hour a day in the afternoons according to the application schedule. The researcher allocated 1 class hour for both age groups each and worked with both groups independently. Two of the activities implemented within the context of the current study are given as examples in the annex section (Annex 2).

No intervention was made to the control groups while the movement activities were being implemented with the experimental groups. It was openly expressed to the control group teachers that a special study would be conducted with the experimental group and that they should not leave their own standard order, otherwise they might interrupt the research. After 9 weeks of application, the experimental and control groups were subjected to post-tests in which priority was given to the experimental group whose recall measurements would be made later.

No study was conducted with the experimental group during the 1-month period after the post-test measurements, and the recall measurements were administered to the experimental group in early June.

\section{Data Analysis}

In the analysis of the collected data, SPSS16 program package was used. In the analysis of the pre-test results of the experimental and control groups, independent samples ttest was used; in the analysis of the pre-test and post-test results of the control group, dependent samples t-test was used; in the analysis of the pre-test and post-test results of the experimental group, dependent samples t-test was used; in the analysis of the post-test and recall test results of the experimental group, dependent samples t-test was used and as the data did not show a normal distribution in the gender pre-test - post-test comparison, Mann 
Whitney U test was used. While t-test conducts analyses on mean scores, Mann Whitney U test conducts analyses on the total scores.

\section{Results}

Before the implementation of the training program, 4 and 5-year old children in the control and experimental groups were subjected to a pre-test and the equivalence of the groups was examined with this measurement.

Table 2. Independent t-test Results Obtained from the Pre-test Scores Regarding the Movement Development of the 4-year Old Children in the Control and Experimental Groups

\begin{tabular}{|c|c|c|c|c|c|c|c|}
\hline Variables & Group & $\mathbf{n}$ & $\mathbf{X}$ & SS & sd & $\mathbf{t}$ & $\mathbf{p}$ \\
\hline Locomotor & Experimental & 16 & 27.000 & 9.549 & 15 & .390 & .702 \\
\hline Maninulative & $\begin{array}{l}\text { Control } \\
\text { Experimental }\end{array}$ & $\begin{array}{l}16 \\
16\end{array}$ & $\begin{array}{l}25.937 \\
25.062\end{array}$ & $\begin{array}{l}1.184 \\
11.607\end{array}$ & 15 & 1165 & 262 \\
\hline Mentpatative & Control & 16 & 30.812 & 15.458 & 10 & -1.105 & .202 \\
\hline Total score & $\begin{array}{l}\text { Experimental } \\
\text { Control }\end{array}$ & $\begin{array}{l}16 \\
16 \\
\end{array}$ & $\begin{array}{l}52.062 \\
56.750 \\
\end{array}$ & $\begin{array}{l}17.268 \\
19.871 \\
\end{array}$ & 15 & -.717 & .484 \\
\hline
\end{tabular}

$\mathrm{p}<.05$

In Table 1, the results of the comparison made between the pre-test scores of the 4-year old control group children and experimental group children having participated in the movement training program are shown. These results show that there is no significant difference between the control and experimental groups in terms of their locomotor skills scores, manipulative skills scores and total motor skills scores ( $p>.05)$.

Table 3. Independent t-test Results Obtained from the Pre-test Scores Regarding the Movement Development of the 5-year Old Children in the Control and Experimental Groups

\begin{tabular}{llllllll}
\hline Variables & Group & $\mathbf{n}$ & $\mathbf{X}$ & SS & sd & t & p \\
\hline \multirow{2}{*}{ Locomotor } & Experimental & 16 & 38.062 & 11.156 & \multirow{2}{*}{-15} & -.782 & \multirow{2}{*}{.446} \\
& Control & 16 & 40.562 & 7.145 & & & \\
Manipulative & Experimental & 16 & 27.562 & 13.880 & 15 & -1.846 & .085 \\
& Control & 16 & 34.250 & 11.767 & & & \\
Total score & Experimental & 16 & 65.625 & 21.181 & \multirow{2}{*}{15} & -1.734 & .103 \\
\hline
\end{tabular}

$\mathrm{p}<.05$

In Table 2, the results of the comparison made between the pre-test scores of the 5-year old control group children and experimental group children having participated in the movement training program are shown. These results show that there is no significant difference between the control and experimental groups in terms of their locomotor skills scores, manipulative skills scores and total motor skills scores ( $p>.05)$.

Table 4. Independent t-test Results Obtained from the Post-test Scores Regarding the Movement Development of the 4-year Old Children in the Control and Experimental Groups

\begin{tabular}{llllllll}
\hline Variables & Group & $\mathbf{n}$ & $\mathbf{X}$ & SS & sd & t & p \\
\hline Running & Experimental & 16 & 10.375 & 1.821 & \multirow{2}{*}{15} & 3.696 & $.002^{*}$ \\
& Control & 16 & 6.625 & 2.986 & & & \\
Standing long jump & Experimental & 16 & 7.500 & 2.683 & 15 & 4.284 & $.001^{*}$ \\
& Control & 16 & 3.937 & 1.569 & & & \\
Sliding step & Experimental & 16 & 10.062 & 2.322 & 15 & 2.611 & $.020^{*}$ \\
Gallop & Control & 16 & 7.562 & 2.421 & 15 & 4.835 & $.000^{*}$
\end{tabular}




\begin{tabular}{|c|c|c|c|c|c|c|c|}
\hline \multirow{3}{*}{ Jumping } & Control & 16 & 6.187 & 5.036 & \multirow{3}{*}{15} & \multirow{3}{*}{3.296} & \multirow{3}{*}{$.005 *$} \\
\hline & Experimental & 16 & 2.437 & 1.631 & & & \\
\hline & Control & 16 & 1.375 & 1.746 & & & \\
\hline \multirow{2}{*}{ Leaping } & Experimental & 16 & 6.562 & 2.965 & \multirow{2}{*}{15} & \multirow{2}{*}{2.692} & \multirow{2}{*}{$.017 *$} \\
\hline & Control & 16 & 3.562 & 2.707 & & & \\
\hline \multirow{2}{*}{ Locomotor } & Experimental & 16 & 49.375 & 10.556 & \multirow{2}{*}{15} & \multirow{2}{*}{5.369} & \multirow{2}{*}{$.000 *$} \\
\hline & Control & 16 & 29.250 & 9.553 & & & \\
\hline \multirow{2}{*}{ Throwing } & Experimental & 16 & 9.437 & 3.501 & \multirow{2}{*}{15} & \multirow{2}{*}{3.054} & \multirow{2}{*}{$.008 *$} \\
\hline & Control & 16 & 5.312 & 4.541 & & & \\
\hline \multirow{2}{*}{ Rolling } & Experimental & 16 & 8.187 & 2.809 & \multirow{2}{*}{15} & \multirow{2}{*}{1.382} & \multirow{2}{*}{. 187} \\
\hline & Control & 16 & 6.562 & 3.244 & & & \\
\hline \multirow{2}{*}{ Kicking } & Experimental & 16 & 8.625 & 4.379 & \multirow{2}{*}{15} & \multirow{2}{*}{4.310} & \multirow{2}{*}{$.001 *$} \\
\hline & Control & 16 & 3.687 & 2.914 & & & \\
\hline \multirow{2}{*}{ Catching } & Experimental & 16 & 9.062 & 1.526 & \multirow{2}{*}{15} & \multirow{2}{*}{2.672} & \multirow{2}{*}{$.017 *$} \\
\hline & Control & 16 & 7.250 & 2.016 & & & \\
\hline \multirow{2}{*}{$\begin{array}{l}\text { Hitting a stationary ball with } \\
\text { a stick }\end{array}$} & Experimental & 16 & 7.062 & 3.473 & \multirow{2}{*}{15} & \multirow{2}{*}{1.091} & \multirow{2}{*}{.293} \\
\hline & Control & 16 & 5.750 & 4.219 & & & \\
\hline \multirow{2}{*}{ Bouncing a ball } & Experimental & 16 & 5.312 & 2.845 & \multirow{2}{*}{15} & 1647 & 120 \\
\hline & Control & 16 & 3.312 & 4.629 & & $1.64 /$ & .120 \\
\hline & Experimental & 16 & 47.687 & 12.213 & 15 & & $002 *$ \\
\hline Manipulative & Control & 16 & 31.875 & 17.480 & 15 & 3.461 & $.003^{*}$ \\
\hline Tatal croro & Experimental & 16 & 97.062 & 20.137 & 15 & 4634 & $000 *$ \\
\hline 1otal score & Control & 16 & 61.125 & 24.819 & 15 & 4.634 & $.000^{2}$ \\
\hline
\end{tabular}

In Table 3, the results of the comparison made between the post-test scores of the 4-year old control group children and experimental group children having participated in the movement training program are shown. These results show that there is a significant difference in the locomotor sub-dimension total score, manipulative total score and motor skills total score in favour of the experimental group $(\mathrm{p}<.05)$.

When the scores of all the skills in the locomotor sub-dimensions were separately compared, a significant difference was found for all the skills in favour of the experimental group $(\mathrm{p}<.05)$. Although the scores obtained for the skills of "rolling", "hitting a stationary ball with a stick" and "bouncing a ball" in the manipulative sub-dimension by the experimental groups children are higher than those of the control group children, the difference between them is not statistically significant. In all the locomotor skills apart from these skills, a significant difference was found in favour of the experimental group children $(\mathrm{p}<.05)$.

Table 5. Independent t-test Results Obtained from the Post-test Scores Regarding the Movement Development of the 5-year Old Children in the Control and Experimental Groups

\begin{tabular}{|c|c|c|c|c|c|c|c|}
\hline Variables & Group & $\mathbf{n}$ & $\mathbf{X}$ & SS & sd & $\mathbf{t}$ & p \\
\hline \multirow{2}{*}{ Running } & Experimental & 16 & 11.750 & .683 & \multirow{2}{*}{15} & \multirow{2}{*}{7.511} & \multirow{2}{*}{$.000 *$} \\
\hline & Control & 16 & 6.625 & 2.895 & & & \\
\hline \multirow{2}{*}{ Standing long jump } & Experimental & 16 & 8.437 & 2.096 & \multirow{2}{*}{15} & \multirow{2}{*}{4.090} & \multirow{2}{*}{$.001 *$} \\
\hline & Control & 16 & 5.125 & 2.526 & & & \\
\hline \multirow{2}{*}{ Sliding step } & Experimental & 16 & 12.437 & 1.750 & \multirow{2}{*}{15} & \multirow{2}{*}{4.461} & \multirow[b]{2}{*}{$.000 *$} \\
\hline & Control & 16 & 9.312 & 1.887 & & & \\
\hline \multirow{2}{*}{ Gallop } & Experimental & 16 & 13.125 & 1.627 & \multirow{2}{*}{15} & \multirow{2}{*}{2.802} & \multirow{2}{*}{$.013^{*}$} \\
\hline & Control & 16 & 10.812 & 3.410 & & & \\
\hline \multirow{2}{*}{ Jumping } & Experimental & 16 & 4.062 & 1.289 & \multirow{2}{*}{15} & \multirow{2}{*}{3.746} & \multirow{2}{*}{$.002 *$} \\
\hline & Control & 16 & 1.750 & 2.175 & & & \\
\hline \multirow{2}{*}{ Leaping } & Experimental & 16 & 9.437 & 1.711 & \multirow{2}{*}{15} & \multirow{2}{*}{2.817} & \multirow{2}{*}{$.013^{*}$} \\
\hline & Control & 16 & 6.500 & 3.559 & & & \\
\hline \multirow{2}{*}{ Locomotor } & Experimental & 16 & 59.250 & 5.458 & \multirow{2}{*}{15} & \multirow{2}{*}{6.522} & \multirow{2}{*}{$.000^{*}$} \\
\hline & Control & 16 & 40.125 & 10.855 & & & \\
\hline
\end{tabular}




\begin{tabular}{|c|c|c|c|c|c|c|c|}
\hline \multirow{2}{*}{ Throwing } & Experimental & 16 & 11.437 & 4.210 & \multirow{2}{*}{15} & \multirow{2}{*}{2.394} & \multirow{2}{*}{$.030 *$} \\
\hline & Control & 16 & 6.875 & 5.725 & & & \\
\hline \multirow{2}{*}{ Rolling } & Experimental & 16 & 9.437 & 2.707 & \multirow{2}{*}{15} & \multirow{2}{*}{1.161} & \multirow{2}{*}{.264} \\
\hline & Control & 16 & 8.375 & 2.848 & & & \\
\hline \multirow{2}{*}{ Kicking } & Experimental & 16 & 13.062 & 2.174 & \multirow{2}{*}{15} & \multirow{2}{*}{8.114} & \multirow{2}{*}{$.000 *$} \\
\hline & Control & 16 & 5.375 & 3.556 & & & \\
\hline \multirow{2}{*}{ Catching } & Experimental & 16 & 9.437 & .813 & \multirow{2}{*}{15} & \multirow{2}{*}{1.126} & \multirow{2}{*}{.278} \\
\hline & Control & 16 & 8.875 & 1.746 & & & \\
\hline \multirow{2}{*}{$\begin{array}{l}\text { Hitting a stationary ball with } \\
\text { a stick }\end{array}$} & Experimental & 16 & 9.750 & 3.660 & \multirow{2}{*}{15} & \multirow{2}{*}{4.614} & \multirow{2}{*}{$.000^{*}$} \\
\hline & Control & 16 & 4.687 & 3.177 & & & \\
\hline \multirow{2}{*}{ Bouncing a ball } & Experimental & 16 & 7.250 & 2.886 & \multirow{2}{*}{15} & \multirow{2}{*}{2.682} & \multirow{2}{*}{$.017 *$} \\
\hline & Control & 16 & 4.375 & 3.612 & & & \\
\hline \multirow{2}{*}{ Manipulative } & Experimental & 16 & 60.375 & 9.864 & \multirow{2}{*}{15} & \multirow{2}{*}{5.461} & \multirow{2}{*}{$.000 *$} \\
\hline & Control & 16 & 38.562 & 13.048 & & & \\
\hline \multirow{2}{*}{ Total score } & Experimental & 16 & 119.625 & 13.970 & \multirow{2}{*}{15} & \multirow{2}{*}{6.606} & \multirow{2}{*}{$.000 *$} \\
\hline & Control & 16 & 78.687 & 20.178 & & & \\
\hline
\end{tabular}

In Table 4, the results of the comparison made between the post-test scores of the 5-year old control group children and experimental group children having participated in the movement training program are shown. These results show that there is a significant difference in the locomotor sub-dimension total score, manipulative total score and motor skills total score in favour of the experimental group $(\mathrm{p}<.05)$.

Although the scores taken for the skills of "rolling" and "catching" in the manipulative subdimension by the experimental group children are higher than those of the control group children, the difference between them is not statistically significant. In all the manipulative skills apart from these skills and in all the skills in the locomotor sub-dimension, a significant difference was found in favour of the experimental group children $\mathrm{p}<.05$.

Table 6. Results of the Dependent Samples t-test Conducted on the Pre-test and Post-test Scores of the 4-year Old Children in the Experimental Group

\begin{tabular}{|c|c|c|c|c|c|c|c|}
\hline Variables & Group & $\mathbf{n}$ & $\mathbf{X}$ & SS & sd & $\mathbf{t}$ & p \\
\hline \multirow{2}{*}{ Running } & Pre-test & 16 & 5.250 & 1.770 & \multirow{2}{*}{15} & \multirow{2}{*}{-9.944} & \multirow{2}{*}{$.000^{*}$} \\
\hline & Post-test & 16 & 10.375 & 1.821 & & & \\
\hline \multirow{2}{*}{ Standing long jump } & Pre-test & 16 & 3.562 & 1.093 & \multirow{2}{*}{15} & \multirow{2}{*}{-11.352} & \multirow{2}{*}{$.000^{*}$} \\
\hline & Post-test & 16 & 10.375 & 1.821 & & & \\
\hline \multirow{2}{*}{ Sliding step } & Pre-test & 16 & 5.125 & 3.575 & \multirow{2}{*}{15} & \multirow{2}{*}{-5.783} & \multirow{2}{*}{$.000^{*}$} \\
\hline & Post-test & 16 & 10.062 & 2.322 & & & \\
\hline \multirow{2}{*}{ Gallop } & Pre-test & 16 & 8.437 & 2.851 & \multirow{2}{*}{15} & \multirow{2}{*}{-4.781} & \multirow{2}{*}{$.000^{*}$} \\
\hline & Post-test & 16 & 12.437 & 3.444 & & & \\
\hline \multirow{2}{*}{ Jumping } & Pre-test & 16 & .750 & 1.238 & \multirow{2}{*}{15} & \multirow{2}{*}{-4.521} & \multirow{2}{*}{$.000^{*}$} \\
\hline & Post-test & 16 & 2.437 & 1.631 & & & \\
\hline \multirow{2}{*}{ Leaping } & Pre-test & 16 & 3.875 & 3.117 & \multirow{2}{*}{15} & \multirow{2}{*}{-3.810} & \multirow{2}{*}{$.002 *$} \\
\hline & Post-test & 16 & 6.562 & 2.965 & & & \\
\hline \multirow{2}{*}{ Locomotor } & Pre-test & 16 & 27.000 & 9.549 & \multirow{2}{*}{15} & \multirow{2}{*}{-11.687} & \multirow{2}{*}{$.000 *$} \\
\hline & Post-test & 16 & 49.375 & 10.556 & & & \\
\hline \multirow{2}{*}{ Throwing } & Pre-test & 16 & 5.125 & 4.617 & \multirow{2}{*}{15} & \multirow{2}{*}{-4.987} & \multirow{2}{*}{$.000^{*}$} \\
\hline & Post-test & 16 & 9.437 & 3.501 & & & \\
\hline \multirow{2}{*}{ Rolling } & Pre-test & 16 & 4.562 & 3.482 & 15 & -3.954 & $001 *$ \\
\hline & Post-test & 16 & 8.187 & 2.809 & 15 & -3.934 & \\
\hline Kicking & Pre-test & 16 & 4.312 & 3.260 & 15 & 4616 & $0 \cap 0 *$ \\
\hline K1CK1ng & Post-test & 16 & 8.625 & 4.379 & 15 & -4.010 & $.000^{2}$ \\
\hline Catching & Pre-test & 16 & 6.750 & 2.175 & 15 & -3522 & $003 *$ \\
\hline calcming & Post-test & 16 & 9.062 & 1.526 & $1 J$ & -5.322 & .005 \\
\hline Hitting a stationary ball with & Pre-test & 16 & 3.437 & 3.539 & 15 & -2.977 & $.009 *$ \\
\hline
\end{tabular}




\begin{tabular}{llllllll} 
a stick & Post-test & 16 & 7.062 & 3.473 & & & \\
\multirow{2}{*}{ Bouncing a ball } & Pre-test & 16 & .875 & 1.258 & 15 & -5.940 & $.000^{*}$ \\
& Post-test & 16 & 5.312 & 2.845 & & & \\
\multirow{2}{*}{ Manipulative } & Pre-test & 16 & 25.062 & 11.607 & 15 & -10.706 & $.000^{*}$ \\
\hline \multirow{2}{*}{ Total score } & Post-test & 16 & 47.687 & 12.213 & & \\
& Pre-test & 16 & 52.062 & 17.268 & \multirow{2}{*}{15} & -14.183 & $.000^{*}$ \\
\hline $\mathrm{p}<.05$ & Post-test & 16 & 97.062 & 20.137 & & &
\end{tabular}

In Table 5, the results of the comparison made between the pre-test and post-test scores of the 4-year old children in the experimental group are shown. These results show that there is a statistically significant difference in the motor skills total score, the locomotor sub-dimension total score and the manipulative sub-dimension total score in favour of the post-test $(\mathrm{p}<.05)$. When the scores taken for all the skills in the locomotor and manipulative sub-dimensions were compared separately, a significant difference was found for all the skills in favour the post-test $(\mathrm{p}<.05)$.

Table 7. Results of the Dependent Samples t-test Conducted on the Pre-test and Post-test Scores of the 5-year Old Children in the Experimental Group

\begin{tabular}{|c|c|c|c|c|c|c|c|}
\hline Variables & Group & $\mathbf{n}$ & $\mathbf{X}$ & SS & sd & $\mathbf{t}$ & $\mathbf{p}$ \\
\hline \multirow{2}{*}{ Running } & Pre-test & 16 & 7.250 & 2.909 & \multirow{2}{*}{15} & \multirow{2}{*}{-6.708} & \multirow{2}{*}{$.000 *$} \\
\hline & Post-test & 16 & 11.750 & .683 & & & \\
\hline \multirow{2}{*}{ Standing long jump } & Pre-test & 16 & 6.000 & 3.098 & \multirow{2}{*}{15} & \multirow{2}{*}{-3.538} & \multirow{2}{*}{$.003^{*}$} \\
\hline & Post-test & 16 & 8.437 & 2.096 & & & \\
\hline \multirow{2}{*}{ Sliding step } & Pre-test & 16 & 8.687 & 4.238 & \multirow{2}{*}{15} & \multirow{2}{*}{-3.491} & \multirow{2}{*}{$.003^{*}$} \\
\hline & Post-test & 16 & 12.437 & 1.750 & & & \\
\hline \multirow{2}{*}{ Gallop } & Pre-test & 16 & 10.375 & 3.862 & \multirow{2}{*}{15} & \multirow{2}{*}{-3.358} & \multirow{2}{*}{$.004 *$} \\
\hline & Post-test & 16 & 13.125 & 1.627 & & & \\
\hline \multirow{2}{*}{ Jumping } & Pre-test & 16 & 1.750 & 2.294 & \multirow{2}{*}{15} & \multirow{2}{*}{-4.125} & \multirow{2}{*}{$.001 *$} \\
\hline & Post-test & 16 & 4.062 & 1.289 & & & \\
\hline \multirow{2}{*}{ Leaping } & Pre-test & 16 & 4.000 & 3.577 & \multirow{2}{*}{15} & \multirow{2}{*}{-5.350} & \multirow{2}{*}{$.000 *$} \\
\hline & Post-test & 16 & 9.437 & 1.711 & & & \\
\hline \multirow{2}{*}{ Locomotor } & Pre-test & 16 & 38.062 & 11.156 & \multirow{2}{*}{15} & \multirow{2}{*}{-9.060} & \multirow{2}{*}{$.000 *$} \\
\hline & Post-test & 16 & 59.250 & 5.458 & & & \\
\hline \multirow{2}{*}{ Throwing } & Pre-test & 16 & 5.000 & 5.006 & \multirow{2}{*}{15} & & \\
\hline & Post-test & 16 & 11.437 & 4.210 & & -4.382 & $.001^{*}$ \\
\hline Polling & Pre-test & 16 & 5.500 & 4.163 & 15 & 4065 & $000 *$ \\
\hline Kolling & Post-test & 16 & 9.437 & 2.707 & 15 & -4.903 & $.000^{*}$ \\
\hline Kickino & Pre-test & 16 & 3.437 & 2.707 & 15 & -12351 & $000 *$ \\
\hline & Post-test & 16 & 13.062 & 2.174 & 15 & & \\
\hline & Pre-test & 16 & 7.562 & 1.824 & & & \\
\hline Catching & Post-test & 16 & 9.437 & .813 & 15 & -3.890 & $.001^{*}$ \\
\hline Hitting a stationary ball with & Pre-test & 16 & 4.937 & 4.373 & & & \\
\hline a stick & Post-test & 16 & 9.750 & 3.660 & 15 & -5.745 & $.000^{*}$ \\
\hline Rouncing a hall & Pre-test & 16 & 1.125 & 3.095 & 15 & 7283 & $000 *$ \\
\hline Bouncing a ball & Post-test & 16 & 7.250 & 2.886 & 15 & -1.283 & $.000^{\pi}$ \\
\hline Maninulative & Pre-test & 16 & 27.562 & 13.880 & 15 & -12803 & $000 *$ \\
\hline Manipulattve & Post-test & 16 & 60.375 & 9.864 & 15 & -12.803 & $.000^{*}$ \\
\hline Total score & Pre-test & 16 & 65.625 & 21.181 & 15 & -15274 & $000 *$ \\
\hline Total score & Post-test & 16 & 119.625 & 13.970 & $1 J$ & -15.214 & .000 \\
\hline
\end{tabular}

$\mathrm{p}<.05$

In Table 6, the results of the comparison made between the pre-test and post-test scores of the 5 -year old children in the experimental group are shown. These results show that there is a statistically significant difference in the motor skills total score, the locomotor sub-dimension total score and the manipulative sub-dimension total score in favour of the post-test $(\mathrm{p}<.05)$. 
When the scores taken for all the skills in the locomotor and manipulative sub-dimensions were compared separately, a significant difference was found for all the skills in favour the post-test $(\mathrm{p}<.05)$.

\section{Discussion and Conclusions}

The aim of the comparison of the results of the pre-tests administered to both the experimental and control groups was to determine the equivalence of the experimental and control groups. In other words, it should be determined that groups are not more advantageous over or superior to each other in terms of the skills to be measured because Karasar (2015, p.97) stated that the fact that the pre-test scores of the experimental and control groups differ significantly will make the interpretations of the comparisons difficult and will mean that the groups are not equal. As a result of the pre-test analyses conducted in the current study, it was found that there is no significant difference between the locomotor skills sub-dimension total score, manipulative skills sub-dimension total score and motor skills total score of the 4 and 5-year experimental group children and 4 and 5-year old control group children; that is, the control and experimental groups were found to be equal.

Post-test results obtained for both the 4-year old children and 5-year old children were found to be significantly different in favour the experimental group, indicating that the implemented movement program developed the skills of the children in the experimental group. The reason for this development can be explained by the fact that children had the chance to try and repeat certain skills with the implemented movement program. As Çağlak-Sarı (2011) and Goodway, Robinson and Crowe (2010) stated, children need to be supported with appropriate movement programs in the maturation stage of the fundamental movements phase. In support of this view, Müniroğlu (1995) stated that children's motor development levels are affected by the environmental conditions they are in. In addition to all this information, Castelli (2019) emphasizes that physical activity programs offer opportunities for children to develop fundamental motor skills. Because reaching the optimal development level of motor skills can only be achieved through practice and reinforcement (Logan, Robinson, Wilson \& Lucas, 2012).

There are many national and international studies in the literature that demonstrate that when a movement program has been implemented, it gives positive results. Venetsanou and Kambas (2009) listed environmental factors affecting children's motor development in order of importance as follows: family, educational institutions and movement programs. The concept of family, which has an effect on the motor development of children, should be considered not only as individual family members, but also as the home environment where individuals live together. In a study, it was emphasized that the effect of home environment on children's motor development decreased. It has been stated that the effect of the developing technology on the decrease of the effect of the home environment on motor development, the inactivity of the children, the decrease in the options for physical activity at home and the decrease in time (Hu, Wu \& Kong, 2021). Unlike home environments, which cannot provide children with sufficient variety or space for physical activity, this deficiency is expected to be eliminated in school environments. Because there is a wider physical activity environment in the school environment and there are professionals (teachers) who will prepare suitable activities for the motor development of children and the development of fundamental movement skills. When we look at the studies comparing the motor development of children with and without pre-school education, it is seen that there are studies indicating that the motor skills and basic movement skills of the children who are educated in pre-school 
education institutions are in better condition (Valadi, 2021). Transferring the technical knowledge acquired in terms of appropriate environment and motor development to children in an accurate and appropriate manner ensures that children have more physical activity opportunities. As research results support, more physical activity leads to further development of motor competence (Barnett, et al. 2016; Niemistö, Finni, Haapala, Cantell, Korhonen, Saakslahti, 2019; Mota, Clark, Bezerra, Lemos, Reuter, Mota, Duncan, \& Martins 2020). According to Venetsanou and Kambas (2009) implementing a movement program for children in educational institutions is necessary and important. Robinson, Wfebster, Logan, Lucas, and Barber (2012) demonstrated the effectiveness of the movement programs prepared by field specialist teachers on children's motor skills. In this regard, it is possible to say that teachers who are experts in the field and know the development of the child well can prepare appropriate programs for children and support the development of the child positively through regular practices. Bozdemir (1995) determined that the motor development of children was positively affected as a result of the movement education program he applied to children who were educated in different institutions. Kobal (2000) found that the gross motor skills of babies who received movement training were more advanced than those who did not receive training. Dursun (2004), on the other hand, in his study examining the effect of the movement training program including fundamental motor skills on the motor development of 6-year old children, determined that there was a significant difference in the motor development of the group in which the movement program was implemented. Şen (2004), in her study examining the effects of physical education practices on the motor development of children attending kindergarten, determined that the motor development of children in the group in which the physical education program was implemented was more advanced than the group in which this program was not implemented. In Wang's (2004) study, which examined the effect of the movement program applied to children aged 3-5 on their motor development, the gross motor skill scores of the children in the experimental and control groups differed significantly in favour of the experimental group. Similarly, Kırıc1 (2008) and Gül (2012) determined that there was a significant difference in the motor development of the children in the experimental group as a result of the movement training they applied to children attending preschool education institutions.

It is seen that the 5-year old children got higher scores than the 4-year old children in all measurements, including the sub-dimensions of the measurement tool and the total score. This shows that 5-year old children are developmentally ahead of 4-year old children, which is an expected result because of the nature of development. Çelebi (1979) determined that the motor skills of older children are at a more advanced level. Similarly, Gülaç (2014), examining the motor development of children aged 3-5, found that the higher the age of the children is, the more advanced their motor development is. However, it is also stated that this natural difference, which is expected developmentally, can be reduced to a lesser extent thanks to the special movement programs to be applied and it can reduce the relative age effect on motor competence (Mecias-Calvo, Arufe-Giraldez, Cons-Ferreiro \& Navarro-Paton, 2021).

It is seen that both 4 and 5-year old children got the lowest scores in all the measurements for the jumping and leaping skills under the subtitle of locomotor. This situation suggests that children generally do not have a lot of chances to experience these movements, that their muscles cannot be strengthened enough and that they have difficulty in doing the movements because they are not adequately exposed to these experiences, which is thought to be the reason for low scores taken from the measurements. Haktanır (2010) stated that there are three areas of change deeply affecting children and second of these three areas is the decrease 
in the interaction of children with the street because of the loss of spaces where children can play freely. Hinkley, Crawford, Salmon, Okely, and Hesketh (2008) highlighted the importance of the environment for children to experience movements, and in their study, they stated that children who spend time outdoors are much more active than those who spend time indoors. Timurkaan (2003) compared the motor skills of children in residential areas with different physical characteristics and concluded that the motor skills of children living in rural areas are better. Fjortoft (2004) determined that the motor development of children who play in nature in natural play environments is significantly different from those of children playing in the playgrounds in institutions.

It was observed that both the 4-year old children and 5-year old children got lower scores from the skills of hitting a stationary ball with a stick and bouncing the ball, which are included in the manipulative sub-dimension. This indicates cultural differences particularly in relation to the skill of hitting a stationary ball with a stick. All the children involved in the study stated that they experienced the skill of hitting a stationary ball with a stick for the first time during the measurements. There were children who said that it was the "baseball" game when they saw the stick and ball. This indicates that since baseball is a popular sport in the United States, it enters the lives of children earlier while it is not very popular in Turkey, so children living in Turkey do not have much experience about this sport. Galberto dos Santos, Pacheco, Basso and Tani (2016), in their study comparing the fundamental motor skills of children from three different countries, determined that the skill of hitting a stationary ball with a stick was more advanced in children living in the United States than in children living in Portugal and China. This shows the effect of culture on this fundamental motor skill. Although a traditional street game tip-cat involves a more complex dimension of hitting a stationary object with a stick, it can be thought as a good way of developing this skill in our country; however, the decreasing number of children playing in the street and the decreasing popularity of street games make the acquisition of this skill by children more difficult unless they are provided with opportunities to engage in such games. The ball bouncing skill is a more difficult one as it requires both hand-eye coordination and keeping a moving object under control. Kayapinar (2002) examined the effect of movement training on hand-eye coordination in children aged 6-7 and determined that the children in the group receiving movement training had better hand-eye coordination and committed fewer mistakes than the other group. It is thought that the children's not being able to play with the ball at home and in the classroom, lack of activities involving using the ball in schools, or lack of opportunities to play with the ball directly in the playgrounds may be obstacles to the development of this skill. Sar1 (2001) compared the motor development of children with and without pre-school education and found that there was no significant difference in their motor development. Özmen (2004), on the other hand, in his study examining the practices of movement education in preschool period, determined that the tools and equipment in the institutions were not at a sufficient level, and half of the teachers participating in the study spent less than 5 hours a week. Kerkez (2006) applied a motor development program to two groups of children; one group of children were under institutional care while the other group of children were living with their families and both of the groups were receiving pre-school education. Although the motor development scores of the children under institutional care were found to be lower than the scores of the children living with their families, the movement program applied showed a positive effect in both groups. Özdenk (2007), Akınbay (2014), and Akın (2015), on the other hand, in their study examining the effect of play on motor development, determined that the motor development of children who play regularly is more advanced. Giagazoglou, Karagianni, Sidiropoulou and Salonikidis (2008) examined the effects of types of educational institutions (private and public), educational environments and the 
opportunities they offer to children on the gross motor development of the children. As a result of the analyses, it was determined that the school type has an effect on children's gross motor skills. They stated that the motor development of children in schools with large open spaces, allowing children to move freely and providing access to appropriate materials is more advanced than the motor development of children in schools that offer children limited and closed spaces. Reunamo, Hakala, Saros, Lehto, Kyhala, and Valtonen (2014), in their research investigating the effect of the educational environment on physical activity in day care homes and pre-school education institutions, determined that the most physically active time of children was the time they played free in the school and found that the rate of being physically active while playing games inside the school lagged behind the rate of being physically active when they were engaged in free play in the open air.

As a result of the current study conducted to investigate the effect of the CATCH Movement Program on children's locomotor and manipulative skills,

- It was determined that the CATCH Movement Program was effective on the development of the motor skills of the 4 and 5-year old children.

- It was found that the movement program applied to children developed all the locomotor (running, standing long jump, sliding step, gallop, jumping and leaping) and all the manipulative skills (throwing, catching, kicking, rolling, hitting a stationary ball with a stick and bouncing ball) of the 4 and 5-year old children.

- It was found that motor skills, which are the combination of locomotor skills and manipulative skills, of both the 4 and 5-year old children also developed.

- It is seen that even if children attend educational institutions, if they are not provided with suitable spaces for movement and appropriate tools and equipment and if they are not supported with movement programs, no difference occurs in their movement development.

\section{Suggestions}

Suggestions for Educators are below:

- Since the activities in the Training Program created from the CATCH Program Movement Activities were prepared by taking the developmental features into consideration, it coincides with the objectives set in the Ministry of National Education Preschool Education Program. In order for educators to better support motor development, they should actively use the Preschool Education Program and be informed about motor development, motor development measurement tools and the use of these tools. In this regard, training programs can be organized for educators.

Suggestions for Researchers are as follows:

- The effectiveness of the Training Program created from the CATCH Program Movement Activities was determined by working with 4 and 5-year old children. By working with children from different age groups, the effect of program in different age groups can be determined.

- In the current study, the Training Program created from the CATCH Program Movement Activities was implemented for 9 weeks. This study period can be spread over a year with regular repetitions and the effects of longer-term movement training can be examined. 
- In the current study, all the measurements and activities were conducted on children with normal development. The CATCH Program movement activities have an activity pool prepared to be applied to children with different disability groups with adaptations, and these activities can be applied to different disability groups or children with developmental disabilities and their effectiveness can be examined.

- The parts of the CATCH Program movement activities that are not included in the current study can be translated and the effectiveness of these activities can be examined.

- The relationship between the CATCH Program movement activities and other areas of development can be examined.

- Using other movement activities in the CATCH Program, different movement programs can be designed, applied to pre-school children, and their state of supporting their development can be examined.

Suggestions made for Program Development are:

- The current study focused on only the movement activities of the CATCH Program. The suitability of the CATCH Program as a whole, which aims to increase the activity of children and give them healthy eating habits to support the healthy development of children, can be examined and used if found appropriate.

- Existing movement programs can be used and expanded, or new movement programs can be developed to support the motor development of children.

\section{Note}

This research was produced from the the first author's doctoral thesis titled " CHAMPS Motor Beceriler Protokolü'nün (CMBP) Türkçeye Uyarlanması ve CATCH Programı Hareket Etkinliklerinin Çocukların Lokomotor ve Nesne Kontrolü Becerileri Üzerindeki Etkisinin İncelenmesi".

\section{References}

Barnett, L.M., Lai, S.K., Veldman, S.L.C., Hardy, L.L., Cliff, D.P., Morgan, P.J., Zask, A., Lubans, D.R., Shultz, S.P., Ridgers, N.D., et al. (2016). Correlates of gross motor competence in children and adolescents: a systematic review and meta-analysis. Sports Med., 46, 1663-1688. DOI 10.1007/s40279-016-0495-z

Baştürk, S. (2009). Bilimsel araştırma yöntemleri [Scientific research methods.]. Ankara: Anı Publishing.

Bozdemir, S. (1995). Kurum bakımı altında bulunan normal ve zihinsel özürlü çocukların motor gelişimine, eğitim etkisinin karşılaştırmalı olarak incelenmesi. [The Effect of education on motor development institutionalized normal and mental retardae children]. Unpublished master's thesis. Hacettepe University, Ankara.

Castelli, D. M. (2019). Motor performance or opportunities to move? What do children need the most? Journal of Sport and Health Science, 8, 149-152.

Cools, W., Martelaer, K., Samaey, C. \& Andries, C. (2011). Fundamental movement skill performance of preschool children in relation to family contex. Journal of Sports Science, 29(7), 649-660.

Çağlak-Sarı, S. (2011). Okul öncesi çocuk ve hareket eğitimi [Preschool children and movement education]. In M. Ormanlıŏlu Uluğ \& G. Karadeniz (Eds.) Okul öncesi çocuk ve... [Preschool child and...] (275-289) Ankara: Nobel Academy Publishing. 
Çelebi, N. (1979). Süt çocukluğu çağı çocuklarının fizik gelişim parametrelerinin ve motor gelişim durumlarının karşılaştırmalı olarak incelenmesi. [Comparative examination of physical development parameters and motor development status of infants]. Unpublished master's thesis. Hacettepe University, Ankara.

Derscheid, L. E., Umoren, J., Kim, S.Y., Henry, B. W. \& Zittel, L. L. (2010). Early childhood teachers' and staff members' perceptions of nutrition and physical activity practices for preschoolers. Journal of Research in Childhood Education, 24(3), 248-265.

Fjortoft, I. (2004). Landscape as playscape: the effects of natural environments on children's play and motor development. Children, Youth and Environments.14(2), 21-44.

Galberto dos Santos, F., Pacheco, M. M., Basso, L. \& Tani, G. (2016). A comparative study of mastery of fundamental movement skills between different cultures. Motricidade, 12(2), 116-126.

Giagazoglou, P., Karagianni, O., Sidiropoulou, M. \& Salonikidis, K. (2008). Effects of the characteristics of two different preschool-type setting on children's gross motor development. European Psychomotricity Journal, 1(2), 54-60.

Goodway, J. D., Robinson, L. \& Crowe, H. (2010). Gender differences in fundamental motor skills development in disadvantaged preschooler from two geographical regions.Research Quarterly for Exercise and Sport, 81(1), 17-24.

Gül, Ö. (2012). Oyun ve hareket temelli büyük kas beceri eğitim programlarının 4-5 yaş çocukların büyük kas becerilerine etkisinin karşılaştırılması. [The comparison of the effect of game and motion-based gross motor skills training programmes on the 4-5 year-old children's gross motor skills]. Unpublished doctoral dissertation. Selçuk University, Konya.

Gülaç, M. (2014). Kütahya'da anaokuluna giden 3-5 yaş grubu çocukların temel motor becerileri düzeylerinin araştırılması. [Research for the level of motor skills of 3-5 years old kindergartners]. Unpublished doctoral dissertation. Dumlupınar University, Kütahya.

Günebakan, T., Saygın, Ö., Gelen, E. \& Karacabey, K. (2009). 3-4 yaş grubu çocuklarda 8 haftalık hareket eğitiminin motor performanslarına etkisi. [The effect of 8-week movement education on motor performance among 3-4 years old children]. e-Journal of New World Sciences Academy Sports Sciences, 4(4), 266-272.

Haktanır, G. (2010). Modern dünyada çocuk olmak [Being a child in the modern world]. In A. Orakçı \& N. R. Gürsoy (Eds.). Geçmişten Geleceğe Okul Öncesi Eğitim [Preschool Education from the Past to the Future] (170-177). Ankara: Okul Öncesi Eğitim Genel Müdürlüğ̈ Yayını.

Hinkley, T., Crawford, D., Salmon, J., Okely, A. D. \& Hesketh, K. (2008). Preschool children and physical activity a review of correlates. American Journal of Preventive Medicine. 34(5), 435-441.

Hu, B.Y., Wu, Z., \& Kong, Z. (2021). Family physical activities choice, parental views of physical activities, and Chinese preschool children's physical fitness and motor development. Early, Childhood Education Journal, https://doi.org/10.1007/s10643021-01190-5

It's Fun To Be Healthy, Early Childhood Curriculum (2011). (2 ${ }^{\text {nd }}$ Edition). New Jersey: FlagHouse.

Karasar, N. (2015). Bilimsel araştırma Yöntemi. (28. Bask1) [Scientific research methods (28th ed.)]. Ankara: Nobel Academy Publishing.

Kayapınar, F. (2002). 6-7 yaş grubu çocuklarda hareket eğitiminin çift el-göz koordinasyonu ve reaksiyon sürelerine etkisi [Effects on movement education, hand-eye coordination and reaction time between 6-7 years old children]. Unpublished master's thesis. Marmara University, İstanbul. 
Kerkez, İ. F. (2006). Oyun ve egzersizin yuva ve anaokuluna giden 5-6 yaş grubu çocuklarda fiziksel ve motor gelişime etkisinin araştırılması [An investigation into a play and movement program on physical and motor features in 5-6 aged children stayed orphanages and preschoolers]. Unpublished doctoral dissertation. Karadeniz Technical University, Trabzon.

Kılıç, Z. (2018). Champs motor beceriler protokolü'nün (cmbp) türkçeye uyarlanması ve catch programı hareket etkinliklerinin çocukların lokomotor ve nesne kontrolü becerileri üzerindeki etkisinin incelenmesi [Adaptation of CHAMPS motor skills protocol (CMSP) to Turkish and examining of the effects of movement activities of $\mathrm{CATCH}$ program on locomotor and object control skills of children]. Unpublished doctoral dissertation. Marmara University, İstanbul.

Kırıcı, H. M. (2008). Okulöncesi eğitim kurumlarındaki 4-6 yaş grubu çocuklarda 8 haftalık hareket eğitiminin motor performansa etkisi [The effect of movement education of eight weeks on the motor performance of 4-6 years old children in preschool]. Unpublished master's thesis. Muğla Sitkı Koçman University, Muğla.

Kobal, G. (2000). Erken eğitim programına devam eden down sendromlu bebeklere verilen motor beceri eğitiminin büyük kas gelişimlerine etkisinin incelenmesi [A Research on the effects of motor skills training on the gross motor development of infants with down's syndrome, attending the early intervention program]. Unpublished doctoral dissertation. Ankara University, Ankara.

Logan, S.W., Robinson, L.E., Wilson, A.E., \& Lucas, W.A. (2012). Getting the fundamentals of movement: a meta-analysis of the effectiveness of motor skill interventions in children. Child: Care, Health and Development, 38(3), 305-315. DOI: 10.1111/j.1365-2214.2011.01307.x

Mecias-Calvo, M., Arufe-Giraldez,V., Cons-Ferreiro, M., \& Navarro-Paton, R. (2021). Is it possible to reduce the relative age effect through an intervention on motor competence in preschool children? Children, 8 (386), 1-10. https://doi.org/10.3390/children8050386

Mota, J.G., Clark, C.C.T., Bezerra, T.A., Lemos, L., Reuter, C.P., Mota, J.A.P.S., Duncan, M.J., \& Martins, C.M.D.L. (2020) Twenty-four-hour movement behaviours and fundamental movement skills in preschool children: a compositional and isotemporal substitution analysis. Journal of Sports Sciences, 38(18), 2071-2079. https://doi.org/10.1080/02640414.2020.1770415

Müniroğlu, R. S. (1995). Anaokullarına devam eden dört-beş yaş grubu çocukların motor gelişim düzeylerine etki eden bazı faktörler üzerine bir araştırma [A Research on some factors effecting the motor development of four-five years old kindergarden children]. Unpublished doctoral dissertation. Ankara University, Ankara.

Nalbant, S. (2015). Psikomotor gelişim [Psychomotor development]. In E. Demir (Ed.) Spor Bilimlerine Giriș [Introduction to Sports Science] (149-176). Ankara: Nobel Academic Publishing.

Niemistö, D., Finni, T., Haapala, E.A., Cantell, M., Korhonen, E., \& Sääkslahti, A. (2019). Environmental Correlates of Motor Competence in Children-The Skilled Kids Study. Int. J. Environ. Res. Public. Health,16(11), 1989. https://doi.org/10.3390/ijerph16111989

Özdenk, Ç. (2007). 6 yaş grubu öğrencilerinin psikomotor gelişimlerinin sağlanmasında oyunun yeri ve önemi [The place and importance of play for pschomotor development of six-years age-group nursery children]. Unpublished master's thesis. Firat University, Elazı $\breve{g}$.

Reunamo, J., Hakala, L., Lehto, S., Kyhala, A. L. \& Valtonen, J. (2014). Children's physical activity in day care and preschool. Early Years, 34(1), 32-48. 
Robinson, L. E., Webster, E. K., Logan, S.W., Lucas, W. A. \& Barber, L. T. (2012). Teaching practices that promote motor skills in early childhood settings. Early Childhood Education Journal, 40, 79-86.

Sarı, K. (2001). Temel psikomotor becerilerin gelişimine farklı eğitim kurumları ve deneklerin özlük niteliklerine bağlı değişkenlerin etkisi [The Effect of different education establishments and variables based on subject characteristics on essential psikomotor skill development. Unpublished master's thesis. Selçuk University, Konya.

Scheffer, C., Ketelhut, K. \& Mohasseb, I. (2007). Does pyhsical education modify the body composition? - results of a longitudinal study of pre-school children. Anthropologischer Anzeiger, 65(2), 193-201.

Sevimay-Özer, D. \& Özer, K. (2014). Çocuklarda Motor Gelişim. (8. Baskı). [Motor Development in Children. (8th Edition)]. Ankara: Nobel Academic Publishing.

Sharma, S., Chuang, R.J, \& Hedberg, A.M. (2011). Pilot-testing CATCH early childhood: a preschool-based healty nutrition and physical activity program. American Journal of Health Education. 42(1), 12-23.

Şen, M. (2004). Anaokuluna devam eden altı yaş çocukların motor gelişimlerine beden eğitimi çalışmalarının etkisinin incelenmesi [A study on the effect of physical education studies on motor development of six-years old children attending kindergarten]. Unpublished master's thesis. Ankara University, Ankara.

Timurkaan, (2003). Farklı fiziki özelliklere sahip yerleşim bölgelerinde yaşayan altı yaş grubu çocukların psikomotor gelişimlerinin karşılaştırılması [In The research the differences in the psychomotor development of six-year-old children who live in neighbourhoods that have different physical characteristic has been compared]. Unpublished master's thesis. İnönü University, Malatya.

Ulutaş, A., Demir, E. \& Yayan, E. H. (2017). Motor gelişim eğitim programının 5-6 yaş çocukların kaba ve ince motor becerilerine etkisinin incelenmesi [The effect of the motor development training program on rough and fine motor development of fivesix-year old children]. Abant İzzet Baysal Üniversitesi Eğitim Fakültesi Dergisi, 17(3), 1523-1538.

Valadi, S. (2021). Association between home motor affordances and motor skills in daycare and non-daycare attending children. Early Child Development and Care, https://doi.org/10.1080/03004430.2021.1917563

Venetsanou, F. \& Kambas, A. (2009). Environmental factors affecting preschoolers' motor development. Early Childhood Education Journal, 37, 319-327.

Wang, J. (2004). A study on gross motor skills of preschool children. Journal of Research in Childhood Education. 19 (1), 32-43.

Williams, H. G., Pfeiffer, K. A., Dowda, M., Jeter, C. Jones, S. \& Pate, R. (2009) a fieldbased testing protocol for assessing gross motor skills in preschool children: the champs motor skills protocol (cmsp). Meas Pyhs Educ Exerc Sci. 13(3), 151-165.

Yarımkaya, E. \& Ulucan, H. (2015). Çocuklarda hareket eğitimi programının motor gelişim üzerine etkisi [The effect of movement education program on the motor development of children]. International Journal of New Trends in Arts, Sports \& Science Education, 4(1), 37-48.

Zecevic, C. A., Tremblay, L., Lovsin, T. \& Michel, L. (2010). Parental influence on young children's physical activity. International Journal of Pediatrics, 2010(7), 1-9. 
Annex 1. Schedule of CATCH Movement Training Program

\begin{tabular}{|c|c|c|c|c|c|}
\hline & & DATE & $D A Y$ & NAME of ACTIVITY & SKILL TYPE \\
\hline \multirow{5}{*}{ 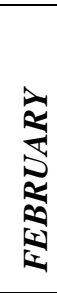 } & 1. & 14.02 .2017 & Tuesday & FIRST MEETING & - \\
\hline & 2. & 16.02 .2017 & Thursday & PRE-TEST & - \\
\hline & 3. & 21.02 .2017 & Tuesday & Walk \& march; Foam noodle train & Locomotor skills - Walking \\
\hline & 4. & 23.02 .2017 & Thursday & Gallop \& slide; Ride the pony & $\begin{array}{l}\text { Locomotor skills }- \text { Galloping, } \\
\text { Sliding }\end{array}$ \\
\hline & 5. & 28.02 .2017 & Tuesday & Jump \& hop; Hop; Skip & $\begin{array}{l}\text { Locomotor skills - Jumping and } \\
\text { hopping }\end{array}$ \\
\hline \multirow{9}{*}{ 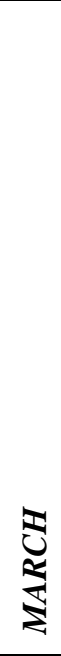 } & 6. & 02.03 .2017 & Thursday & Rainbow fish game & Locomotor skills - all skills \\
\hline & 7. & 07.03 .2017 & Tuesday & GENERAL REPETITION & Locomotor skills - all skills \\
\hline & 8. & 09.03 .2017 & Thursday & Roll it; Balloon Challenge & $\begin{array}{l}\text { Manipulative skills }- \text { rolling, } \\
\text { catching, striking }\end{array}$ \\
\hline & 9. & 14.03 .2017 & Tuesday & Catch it; Beach ball volleyball & $\begin{array}{l}\text { Manipulative skills }- \text { Catching, } \\
\text { tossing, bouncing }\end{array}$ \\
\hline & 10. & 16.03 .2017 & Thursday & Beach ball challenge & $\begin{array}{l}\text { Manipulative skills - Throwing, } \\
\text { catching, bouncing }\end{array}$ \\
\hline & 11. & 21.03 .2017 & Tuesday & Throw it & Manipulative skills - Throwing \\
\hline & 12. & 23.03.2017 & Thursday & Massy backyard; Beanbag toss & $\begin{array}{l}\text { Manipulative skills - Throwing, } \\
\text { catching, rolling }\end{array}$ \\
\hline & 13. & 28.03.2017 & Tuesday & $\begin{array}{l}\text { Jumping frogs on lily pads; } \\
\text { Beanbag crazy }\end{array}$ & $\begin{array}{l}\text { Locomotor \& manipulative skills - } \\
\text { walking, jumping, throwing, } \\
\text { catching }\end{array}$ \\
\hline & 14. & 30.03 .2017 & Thursday & Beach ball partner challenges & $\begin{array}{l}\text { Manipulative skills }- \text { rolling, } \\
\text { throwing, catching }\end{array}$ \\
\hline \multirow{8}{*}{$\underset{\downarrow}{\grave{2}}$} & 15. & 04.04 .2017 & Tuesday & Hug the bug & Manipulative skills - bouncing \\
\hline & 16. & 06.04 .2017 & Thursday & Throw then go; Beanbag crazy & $\begin{array}{l}\text { Locomotor \& manipulative skills - } \\
\text { walking in different forms, } \\
\text { throwing }\end{array}$ \\
\hline & 17. & 11.04.2017 & Tuesday & $\begin{array}{l}\text { Jumping frogs on lily pads; Frogs } \\
\text { and sinking lily pads }\end{array}$ & $\begin{array}{l}\text { Locomotor \& manipulative skills - } \\
\text { walking, jumping, throwing, } \\
\text { catching }\end{array}$ \\
\hline & 18. & 13.04 .2017 & Thursday & GENERAL REPETITION & $\begin{array}{l}\text { Locomotor \& manipulative skills - } \\
\text { all skills }\end{array}$ \\
\hline & 19. & 18.04 .2017 & Tuesday & Kick it; Ball handling skills & $\begin{array}{l}\text { Locomotor \& manipulative skills - } \\
\text { walking, running, , kicking }\end{array}$ \\
\hline & 20. & 20.04 .2017 & Thursday & Under control; Score & $\begin{array}{l}\text { Locomotor \& manipulative skills - } \\
\text { walking, running, , kicking }\end{array}$ \\
\hline & 21. & 25.04 .2017 & Tuesday & GENERAL REPETITION & $\begin{array}{l}\text { Locomotor \& manipulative skills - } \\
\text { all skills }\end{array}$ \\
\hline & 22. & 27.04 .2017 & Thursday & POST-TEST & - \\
\hline$\underset{z}{z}$ & 23. & $\begin{array}{l}01.05 .2017 \\
31.05 .2017\end{array}$ & - & Free weeks before permanence test & - \\
\hline$\sum_{\substack{1 \\
\vdots}}^{\infty}$ & 24. & 01.06 .2017 & - & PARMANENCE TEST & - \\
\hline
\end{tabular}




\section{Annex 2.}

Name of Activity: Roll It

Equipment: 1 playground ball per pair of children and one poly spot per child

Skill Themes: Rolling and catching; eye-hand coordination

\section{Organization:}

1- Children work in pairs.

2- Arrange the poly spots in two lines, approximately two feet apart. Make sure there is plenty of space on each side of spots for movement.

3- Partners sit on their own poly spot with legs straddled facing their partner.

\section{Description:}

1- This simple activity allows children to become comfortable manipulating a ball.

2- The object it to roll the ball so his partner can catch it.

3- The child who catches or captures the ball will then stand up, walk, or run around his partner (holding the ball), and return to his spot to roll it back.

4- Remind children to roll the ball. Throwing and bouncing are not okay.

\section{Teaching Suggestions:}

1- Demonstrate the activity with two children before the whole class participates.

2- Allow them to move farther away from each other as they improve.

3- Remind children that they will have greater aim if they roll the balls gently.

\section{Adapted Ideas:}

1- Children who use mobility devices may be transferred to seated position on the floor if appropriate. Children who cannot sit on the floor may roll a ball across a table to a partner while seated in a chair or wheelchair if appropriate.

2- Children who use wheelchairs and have limited upper body movement may be allowed to roll a ball on their lap trays. Ball sizes and weights may be changed when appropriate. An adult should provide close supervision and assistance.

3- Children with visual impairments may participate with a sighted guide. Beeper devices may be used as auditory cues for which direction the roll the ball.

4- Children with auditory impairments will require modeling for success. Sign language and/or pictures may be used clearer communication. 